\title{
IZABELA LIPIŃSKA*
}

ORCID: 0000-0003-2884-0733

IZABELA HASIŃSKA**

ORCID: 0000-0002-2510-0310

\section{Z problematyki hodowli zwierząt gospodarskich w świetle nowych regulacji prawnych}

1. Przez „hodowlę zwierząt gospodarskich” należy rozumieć ocenę wartości użytkowej i hodowlanej, selekcję oraz dobór osobników do kojarzenia prowadzony w warunkach prawidłowego chowu ${ }^{1}$. Jak podkreśla Johannes A.M. van Arendonk, zmierza ona do świadomego wyboru rodziców następnego pokolenia oraz ich linii lub rasy z uwzględnieniem pewnej kombinacji cech, które hodowca chce udoskonalić2. Hodowla jest postrzegana jako ingerencja człowieka w procesy biologiczne zwierząt. Stanowi swego rodzaju narzędzie do osiągania pewnych celów, co uzasadnia konieczność objęcia jej określonymi normami prawnymi. Szczególne znaczenie ma w tym zakresie rozporządzenie Parlamentu Europejskiego i Rady (UE) 2016/1012, które stosuje się od 1 listopada 2018 r. $^{3}$

* Uniwersytet Przyrodniczy w Poznaniu.

** Uniwersytet Przyrodniczy w Poznaniu.

${ }^{1}$ H. Pawlak, M. Lipiński, Leksykon zootechniczny, Poznań 2016, s. 68-69.

2 J.A.M. van Arendonk, Cele hodowli zwierząt: zrównoważenie wydajności i wpływu na środowisko, „Przegląd Hodowlany” 2011, nr 9, s. 1-4.

${ }^{3}$ Rozporządzenie Parlamentu Europejskiego i Rady (UE) 2016/1012 z 8 czerwca 2016 r. w sprawie zootechnicznych i genealogicznych warunków dotyczących hodowli zwierząt hodowlanych czystorasowych i mieszańców świni, handlu nimi i wprowadzania ich na terytorium Unii oraz handlu ich materiałem biologicznym wykorzystywanym do rozrodu i jego wprowadzania 
Przedmiotem artykułu są zagadnienia związane z ustaleniem zootechnicznych i genealogicznych warunków hodowli zwierząt gospodarskich, które zostały włączone do unijnego porządku prawnego. Chodzi w szczególności o hodowlę zwierząt czystorasowych oraz mieszańców świń. W pierwszym przypadku są to zwierzęta gospodarskie takich gatunków, jak bydło, świnie, owce, kozy, oraz gatunków z rodziny koniowatych, które są wpisane lub zarejestrowane i kwalifikują się do wpisania w sekcji głównej księgi hodowlanej (art. 2 pkt 1, 9 i 10 rozporządzenia 2016/2012). Natomiast w drugim - zwierzęta wpisane do rejestru hodowlanego, będące wynikiem planowego krzyżowania lub wykorzystywane do planowanego krzyżowania: a) świń hodowlanych czystorasowych pochodzących z różnych ras lub linii hodowlanych, b) świń hodowlanych będących wynikiem krzyżowania (hybrydy) różnych ras lub linii hodowlanych, c) świń hodowlanych należących do jednej z wymienionych kategorii. Przyjęty podział na zwierzęta czystorasowe i mieszańce implikuje stosowanie określonych instrumentów prawnych.

Wybór tematyki badawczej uzasadnia wiele względów, w tym względy poznawcze, społeczno-gospodarcze oraz praktyczne. Jeśli chodzi o względy poznawcze, to regulacja prawna dotycząca hodowli zwierząt gospodarskich i problemów z nią związanych wciąż jest dość słabo znana. Kwestie te stanowią przedmiot prawa unijnego od kilkudziesięciu lat, a szczególnego znaczenia nabrały dopiero po wejściu w życie rozporządzenia 2016/1012. Przyjęte $\mathrm{w}$ nim rozwiązania prawne kształtowane były uprzednio przez 26 aktów normatywnych, w dużej mierze dyrektyw ${ }^{4}$. Oprócz zawartych w nich podstawowych instrumentów prawodawca wprowadził też pewne nowe rozwiązania prawne.

Z kolei względy społeczno-gospodarcze są bardzo zróżnicowane. Należy zauważyć, że hodowla zwierząt gospodarskich ma w unijnym rolnictwie strategiczne znaczenie. W 2017 r. wartość produkcji zwierzęcej i produktów zwierzęcych w UE-28 wyniosła 170 mld EUR, co stanowi 40\% działalności rolniczej ${ }^{5}$. Dominuje sektor mleczny $(13,9 \%)$, następne są: produkcja wieprzowiny $(8,9 \%)$, wołowiny, owiec i kóz $(8,2 \%)$, drobiu $(35 \%)$ i jaj $(2,4 \%)^{6}$.

na terytorium Unii oraz zmieniające rozporządzenie (UE) nr 652/2014, dyrektywy Rady 89/608/ EWG i 90/425/EWG i uchylające niektóre akty w dziedzinie hodowli zwierząt (,,rozporządzenie w sprawie hodowli zwierząt”) (Dz. Urz. UE L 171 z 29.06.2016, s. 66-143).

${ }^{4}$ E. Martyniuk, A. Chełmińska, Nowa legislacja UE dotyczaca hodowli i obrotu zwierzętami - najważniejsze elementy, „Przegląd Hodowlany” 2017, nr 4, s. 47-53.

${ }_{5}$ Agricultural and farm income, European Commission, DG Agriculture and Rural Development, and Rural Development, Brussels 2018.

${ }^{6}$ J.L. Peyraud, M. MacLeod, Study on Future of EU livestock: how to contribute to a sustainable agricultural sector? Final Report, European Commission, Brussels 2020, s. 1. 
Hodowla zwierząt gospodarskich jest bardzo ważna dla wielu regionów i rolnictwa europejskiego, a 58\% europejskich gospodarstw rolnych posiada zwierzęta. Ponadto pod względem gospodarczym i społecznym hodowla stanowi część dziedzictwa kulturowego Unii, pozwalając na utrzymanie tradycyjnych ras i linii lokalnych. Warto również wspomnieć, że przyczynia się do zapewnienia bezpieczeństwa żywnościowego Unii, a także jest źródłem dochodów ludności wiejskiej. Europejskie gospodarstwa hodowlane zatrudniają ok. 4 milionów osób ${ }^{7}$. Hodowla odnosi się do trzech powiązanych ze sobą zjawisk, tj. rozrodu, dziedziczenia i genetycznego doskonalenia nowych pokoleń. Łącznie stanowią one źródło innowacji w produkcji. Odbywa się ona w pozornie naturalnych, lecz optymalnych warunkach dla rozwoju zwierzęcia. Hodowla pozwala na zwiększenie występowania u zwierząt pożądanych cech genetycznych, np. odporności na choroby, przyrostu czy wydajności. Istotne jest, że postęp genetyczny w tym zakresie może zwiększyć produkcję przy ograniczeniu negatywnego oddziaływania na środowisko. Ponadto pozwala na ochronę różnorodności biologicznej oraz przyczynia się do uczciwego i sprawiedliwego podziału korzyści wynikających z wykorzystania zasobów genetycznych ${ }^{8}$.

Rozważana tematyka jest również ważna ze względów praktycznych. W efekcie selekcji i hodowli osiągnięto bowiem znaczne postępy jeśli chodzi o rozwój cech związanych z wydajnością zwierząt utrzymywanych w warunkach fermowych, co doprowadziło do zmniejszenia kosztów produkcji na poziomie gospodarstw. Nie zawsze towarzyszyła temu jednak dbałość o dobrostan zwierząt oraz środowisko. W związku z tym została przyjęta regulacja na poziomie unijnym, której celem jest zapewnienie zharmonizowanego podejścia do obrotu zwierzętami hodowlanymi i ich materiałem biologicznym. Należy podkreślić, że zasoby genetyczne, które są częścią bioróżnorodności w rolnictwie, stanowią podstawę zrównoważonego rozwoju sektora hodowlanego, a także stwarzają możliwości dostosowania zwierząt do zmieniających się warunków środowiskowych i produkcyjnych oraz zapotrzebowania rynku i potrzeb konsumentów. Wskazane względy praktyczne mogą ułatwić proces stanowienia i stosowania prawa w zakresie hodowli i rozrodu zwierząt. Regulacje prawne powinny przyczyniać się do zachowania zwierzęcych zasobów genetycznych oraz ochrony bioróżnorodności, w tym do utrzymania dziedzictwa kulturowego. Wymaga to jednak

${ }^{7}$ C. Roguet, C. Gaigné, V. Chatellier, S. Cariou, M. Carlier, R. Chenut, K. Daniel, C. Perrot, Spécialisation territoriale et concentration des productions animales européennes: état des lieux et facteurs explicatifs, „INRA Productions Animales” 2015, nr 28, s. 5-22.

${ }^{8}$ Decyzja Rady 93/626/EWG z 25 października 1993 r. dotycząca zawarcia Konwencji o różnorodności biologicznej (Dz. Urz. L 309 z 13.12.1993, s. 1). 
kompleksowości i jednolitego podejścia do wszystkich podmiotów zaangażowanych w hodowlę oraz usystematyzowania jej przedmiotu.

Celem rozważań jest odpowiedź na pytanie, czy przyjęte na poziomie unijnym normy prawne w zakresie hodowli zwierząt gospodarskich służą jej właściwej organizacji oraz czy ustawodawca krajowy przewidział odpowiednie rozwiązania pozwalające na należyte wykonanie prawa Unii Europejskiej.

2. Zagadnienia związane $\mathrm{z}$ hodowlą zwierząt na poziomie Wspólnoty były początkowo kształtowane na mocy dyrektyw odnoszących się do poszczególnych kierunków produkcji. Prawodawca przyjął założenie, że hodowla zajmuje istotne miejsce w rolnictwie oraz stanowi ważne źródło dochodu ludności wiejskiej. Począwszy od lat 70., większość państw członkowskich w ramach krajowych ram polityki hodowlanej starało się promować produkcję żywca spełniającego określone normy zootechniczne. Ponadto próbowały one zniwelować rozbieżności mogące utrudniać handel wewnątrz Wspólnoty. Prawodawca, formułując założenia poszczególnych dyrektyw, przyjął dwa zasadnicze cele. Po pierwsze, umożliwienie rozwoju hodowli zwierząt gospodarskich przy uregulowaniu handlu zwierzętami hodowlanymi i ich materiałem biologicznym wykorzystywanym do rozrodu oraz wprowadzania ich na terytorium Unii, a w rezultacie utrzymanie konkurencyjności unijnego sektora hodowli zwierząt ${ }^{9}$. Po drugie, zapobieżenie utrzymywaniu lub przyjmowaniu przez państwa członkowskie przepisów krajowych dotyczących dopuszczania do celów hodowli zwierząt hodowlanych gatunków bydła i świń oraz produkcji i wykorzystywania ich nasienia, oocytów i zarodków, co mogłoby stanowić zakaz, ograniczenie lub przeszko-

${ }^{9}$ Ramy prawne dla prawa Unii w zakresie hodowli zwierząt hodowlanych czystorasowych gatunków bydła, świn, owiec, kóz i koniowatych oraz mieszańców świni zostały określone w dyrektywie Rady 88/661/EWG z 19 grudnia 1988 r. w sprawie norm zootechnicznych mających zastosowanie do zwierząt hodowlanych z gatunku świń (Dz. Urz. L 382 z 31.12.1988, s. 36), dyrektywie Rady 89/361/EWG z 30 maja 1989 r. dotyczącej owiec i kóz hodowlanych czystorasowych (Dz. Urz. L 153 z 6.06.1989, s. 30), dyrektywie Rady 90/427/EWG z 26 czerwca 1990 r. w sprawie zootechnicznych i genealogicznych warunków handlu wewnątrzwspólnotowego koniowatymi (Dz. Urz. L 224 z 18.08.1990, s. 55), dyrektywie Rady 91/174/EWG z 25 marca 1991 r. ustanawiającej wymogi zootechniczne i rodowodowe przy wprowadzaniu do obrotu zwierząt czystorasowych oraz zmieniającej dyrektywy 77/504/EWG oraz 90/425/EWG (Dz. Urz. L 85 z 5.04.1991, s. 37), dyrektywie Rady 94/28/WE z 23 czerwca 1994 r. ustanawiającej zasady odnoszące się do warunków genealogicznych i zootechnicznych stosowanych w przywozie z państw trzecich zwierząt, ich nasienia, komórek jajowych i zarodków oraz zmieniającej dyrektywę 77/504/EWG w sprawie zwierząt hodowlanych czystorasowych z gatunku bydła (Dz. Urz. L 178 z 12.07.1994, s. 66), dyrektywie Rady 2009/157/WE z 30 listopada 2009 r. w sprawie zwierząt hodowlanych czystorasowych z gatunku bydła (Dz. Urz. L 323 z 10.12.2009, s. 1). 
dę w handlu w odniesieniu do krycia naturalnego, sztucznego unasienniania bądź pozyskiwania nasienia, oocytów lub zarodków ${ }^{10}$.

Na podstawie wspomnianych dyrektyw przy udziale specjalnie powołanego Stałego Komitetu ds. Zootechniki ${ }^{11}$ Komisja przyjęła szereg decyzji określających kryteria zatwierdzania lub uznawania organizacji hodowlanych i stowarzyszeń hodowców, wpisywania zwierząt hodowlanych do ksiąg hodowlanych i stadnych, dopuszczania zwierząt hodowlanych czystorasowych gatunków owiec i kóz do hodowli i sztucznego unasienniania, oceny wartości użytkowej i oceny genetycznej zwierząt hodowlanych gatunków bydła, świń, owiec i kóz oraz określania świadectw hodowlanych lub zootechnicznych dla handlu zwierzętami hodowlanymi i ich materiałem biologicznym wykorzystywanym do rozrodu. Ponadto przygotowała wykaz podmiotów zajmujących się hodowlą w państwach trzecich oraz wzory świadectw hodowlanych lub zootechnicznych do celów wprowadzania na terytorium Unii zwierząt hodowlanych oraz ich nasienia, oocytów i zarodków ${ }^{12}$.

Pewne rozproszenie aktów normatywnych dotyczących hodowli oraz brak ich spójności na przestrzeni lat przyczyniły się do podjęcia działań w kierunku uproszczenia i ujednolicenia prawa w tym zakresie. Formułując treść rozporządzenia 2016/1012, prawodawca przyjął kilka założeń: po pierwsze, umożliwienie dostępu do handlu na podstawie zasad mających zastosowanie do uznawania związków hodowców zajmujących się rasami oraz zatwierdzania ich odpowiednich programów hodowlanych; po drugie, określenie zasad wpisywania zwierząt hodowlanych czystorasowych do sekcji głównej księgi hodowlanej oraz do poszczególnych klas sekcji głównej; po trzecie, ustanowienie rozwiązań prawnych dotyczących przeprowadzania oceny wartości użytkowej i oceny genetycznej, dopuszczania zwierząt hodowlanych do hodowli oraz sfomułowania treści świadectw zootechnicznych.

W efekcie prac legislacyjnych prawodawca przyjął kompleksowy akt prawny, który objął swoim zakresem treści ujmowane dotąd w dyrektywach. Zakres jego normowania, według art. 1 ust. 1 rozporządzenia 2016/1012, obejmuje: a) zootechniczne i genealogiczne zasady handlu zwierzętami hodowlanymi i ich materiałem biologicznym wykorzystywanym do rozrodu

${ }^{10}$ Dyrektywa Rady 87/328/EWG z 18 czerwca 1987 r. w sprawie dopuszczania zwierząt hodowlanych czystorasowych z gatunku bydła do celów hodowlanych (Dz. Urz. L 167 z 26.06.1987, s. 54), dyrektywa Rady 90/118/EWG z 5 marca 1990 r. w sprawie dopuszczania do hodowli czystorasowych świń hodowlanych (Dz. Urz. L 71 z 17.03.1990, s. 34), dyrektywa Rady 90/119/EWG z 5 marca 1990 r. w sprawie dopuszczenia do hodowli mieszańców świń hodowlanych (Dz. Urz. L 71 z 17.03.1990, s. 36).

${ }^{11}$ Decyzja Rady 77/505/EWG z 25 lipca 1977 r. ustanawiająca Stały Komitet ds. Zootechniki (Dz. Urz. L 206 z 12.08.1977, s. 11).

12 Zob. wątek nr 5 rozporządzenia 2016/1012. 
oraz ich wprowadzania na terytorium Unii; b) zasady uznawania związków hodowców i przedsiębiorstw hodowlanych oraz zatwierdzania ich programów hodowlanych; c) prawa i obowiązki hodowców, związków hodowców i przedsiębiorstw hodowlanych; d) zasady wpisywania zwierząt hodowlanych do ksiąg hodowlanych i rejestrów hodowlanych oraz zasady dopuszczania do hodowli zwierząt hodowlanych i ich materiału biologicznego wykorzystywanego do rozrodu; e) zasady przeprowadzania oceny wartości użytkowej i oceny genetycznej zwierząt hodowlanych; f) zasady wydawania świadectw zootechnicznych dla zwierząt hodowlanych i ich materiału biologicznego wykorzystywanego do rozrodu; g) zasady dotyczące przeprowadzania kontroli urzędowych, zwłaszcza w związkach hodowców i przedsiębiorstwach hodowlanych, oraz zasady wykonywania innych czynności urzędowych; h) zasady pomocy i współpracy administracyjnej oraz zasady egzekwowania prawa przez państwa członkowskie; i) zasady dotyczące przeprowadzania przez Komisję kontroli w państwach członkowskich i państwach trzecich.

Prawodawca ograniczył zarazem jego skuteczność tylko do zwierząt hodowlanych i ich materiału biologicznego wykorzystywanego do rozrodu w przypadku, gdy zwierzęta te lub potomstwo powstałe $\mathrm{z}$ ich materiału biologicznego wykorzystywanego do rozrodu mają zostać wpisane do ksiąg hodowlanych jako zwierzęta hodowlane czystorasowe lub zarejestrowane w rejestrach hodowlanych jako mieszańce świni (art. 1 ust. 2 rozporządzenia 2016/1012).

Jak wspomniano wyżej, jednym z celów ujednolicenia przepisów było umożliwienie płynnego i niezakłóconego obrotu. Odpowiednio zgodnie $\mathrm{z}$ art. 3 rozporządzenia handel zwierzętami hodowlanymi i ich materiałem biologicznym wykorzystywanym do rozrodu oraz wprowadzanie tych zwierząt i ich materiału biologicznego wykorzystywanego do rozrodu na terytorium Unii nie mogą być zakazywane, ograniczane ani utrudniane z przyczyn zootechnicznych lub genealogicznych. Jedyne ograniczenia, jakie mogą się pojawić, wynikają z omawianego rozporządzenia. Jednocześnie hodowcy, ich związki, przedsiębiorstwa hodowlane i podmioty zajmujące się hodowlą nie mogą być dyskryminowane ze względu na państwo ich pochodzenia ani na państwo pochodzenia ich zwierząt hodowlanych lub materiału biologicznego.

Jednym z najbardziej istotnych instrumentów hodowli jest program hodowlany. Oznacza on szereg systematycznych działań, w tym rejestrowanie, selekcję, hodowlę i wymianę zwierząt hodowlanych oraz ich materiału biologicznego wykorzystywanego do rozrodu, które są opracowane i realizowane w celu zachowania lub ulepszenia pożądanych fenotypowych lub genetycznych cech w populacji będącej celem hodowli (art. 3 pkt 26). Programy hodowlane powinny obejmować dostatecznie dużą liczbę zwie- 
rząt. Hodowcy zaś wspierają i rozwijają u tych zwierząt pożądane cechy lub gwarantują zachowanie rasy zgodnie z celami przyjętymi powszechnie przez ich uczestników. Program ustala się oddzielnie dla każdej rasy zwierząt ze względu na jej szczególne cechy mające znaczenie dla produkcji. Przykładowo celem takiego programu dla rasy bydła Angus jest utrzymanie lub doskonalenie charakterystycznych cech użytkowych, takich jak: bardzo dobra wydajność rzeźna, łatwość wycieleń czy dobra mleczność matek. Program obejmuje szczegółową charakterystykę i wzorzec rasy, obszar geograficzny, na którym program będzie realizowany; sposób identyfikacji zwierząt; cele programu; informacje o decyzjach podjętych na podstawie rozporządzenia oraz dopuszczalnych odstępstwach; ocenę wartości użytkowej oraz informacje o świadectwach zootechnicznych.

Nad realizacją poszczególnych programów czuwają związki hodowców. Należy przez nie rozumieć stowarzyszenie hodowców, organizację hodowlaną lub podmiot publiczny uznane przez właściwy organ państwa członkowskiego. Ich działania obejmują zwierzęta hodowlane czystorasowe wpisane do ksiąg hodowlanych prowadzonych lub założonych przez taki związek. Z kolei w przypadku mieszańców świń program jest prowadzony przez przedsiębiorstwo hodowlane. Może nim być uznane stowarzyszenie hodowców, organizacja hodowlana, prywatne przedsiębiorstwo prowadzące działalność w zamkniętym systemie produkcji lub podmiot publiczny. Uznanie, o którym mowa, wiąże się z koniecznością spełnienia kilku przesłanek: muszą one posiadać osobowość prawną, statut oraz regulację wewnętrzną pozwalającą na równe traktowanie hodowców, odpowiednią populację zwierząt, przygotowaną kadrę, odpowiednią bazę materialną oraz wypracowane procedury kontroli pochodzenia zwierząt. Ponadto każdy związek musi realizować co najmniej jeden program hodowlany.

Warto podkreślić, że w omawianym rozporządzeniu prawodawca rozdzielił kwestie dotyczące uznawania związków hodowców i przedsiębiorstw hodowlanych oraz przewidział dla nich odrębne procedury. Ponadto sprecyzował prawa i obowiązki hodowców, związków hodowców i przedsiębiorstw hodowlanych, ustanawiając jako fundamentalną zasadę równego ich traktowania przez związki hodowców oraz niezależność związków w określaniu celów programów hodowlanych.

Prawodawca umożliwił także rozszerzenie terytorium geograficznego, na którym prowadzone są programy hodowlane. W przypadku, gdy związek hodowców lub przedsiębiorstwo hodowlane zamierza zrealizować program hodowlany dotyczący zwierząt hodowlanych trzymanych w innym państwie członkowskim, ma ono obowiązek powiadomienia o tym fakcie właściwy organ, który je uznał. Jednocześnie prawodawca nałożył na nie obowiązek 
powiadamiania właściwego organu w tym państwie w terminie wskazanym w rozporządzeniu (art. 12 ust. 1 i 2 ). W ciągu 90 dni od daty otrzymania powiadomienia organ ten może odmówić zatwierdzenia prowadzenia na swoim terytorium programu hodowli. Przyczyny odmowy zostały enumeratywnie wskazane w treści rozporządzenia (art. 12 ust. 3). Przykładowo odmawia się zatwierdzenia kolejnego programu hodowlanego, który zagroziłby programowi już realizowanemu przez inny związek hodowców dla tej samej rasy, już zatwierdzonemu w tym innym państwie członkowskim w odniesieniu do co najmniej: a) zasadniczych cech rasy lub głównych celów tego programu hodowlanego; b) zachowania rasy lub różnorodności genetycznej w obrębie tej rasy; c) w przypadku gdy celem tego programu hodowlanego jest zachowanie rasy zagrożonej lub rasy autochtonicznej, która nie występuje powszechnie na co najmniej jednym obszarze Unii.

Na mocy rozporządzenia wprowadzone zostały także przepisy dotyczące kontroli urzędowych dokonywanych zarówno przez państwa członkowskie, jak i na poziomie UE przez Komisję. Ich przeprowadzanie ma na celu zapewnienie zharmonizowanego podejścia do handlu zwierzętami hodowlanymi i ich materiałem biologicznym, a także pewnych programów hodowlanych, które mają nie tylko złożoną strukturę, ale także transgraniczny i międzynarodowy charakter. Ich kontrola może być zatem bardziej efektywna na poziomie Unii.

Ostatnim novum legislacyjnym są odstępstwa dla rasy zagrożonej. Należy przez nią rozumieć rasę lokalną uznaną przez państwo członkowskie za zagrożoną, genetycznie dostosowaną do jednego lub większej liczby tradycyjnych systemów produkcji lub środowisk w tym państwie członkowskim, której status zagrożenia został naukowo potwierdzony (art. 2 pkt 24). W przypadku rasy zagrożonej związek hodowców może zakazać lub ograniczyć wykorzystywanie zwierząt, $w$ tym ich materiału biologicznego do rozrodu, jeżeli mogłoby ono zagrozić jej zachowaniu lub różnorodności genetycznej. Z kolei państwo członkowskie może zezwolić na pozyskiwanie, produkowanie, przetwarzanie i przechowywanie w celu zachowania rasy materiału biologicznego w centrum pozyskiwania lub przechowywania nasienia bądź w centrum przechowywania zarodków.

Jeżeli rasa zniknęła lub jest zagrożona zaniknięciem, to prawodawca przewiduje możliwość jej „rekonstrukcji”. Istotną rolę odgrywa w tym przypadku związek hodowców. Gdy zamierza ona odtworzyć rasę, która wyginęła lub jest poważnie zagrożona wyginięciem, państwo członkowskie może zezwolić mu na wpisywanie do sekcji głównej księgi hodowlanej potomstwa zwierząt hodowlanych czystorasowych odtwarzanej rasy lub zwierząt hodowlanych czystorasowych, lub potomstwa zwierząt hodowla- 
nych czystorasowych innych ras, uczestniczących w odtworzeniu tej rasy, lub każdego zwierzęcia, które związek hodowców uzna za posiadające cechy odtwarzanej rasy oraz - w stosownych przypadkach - spełniające minimalne wymogi wartości użytkowej określone w programie hodowlanym. Niemniej wpis wymaga spełnienia pewnych przesłanek dotyczących księgi hodowlanej (art. 19 ust. 2).

3. Wejście w życie rozporządzenia nr 2016/1012 wymogło na polskim ustawodawcy podjęcie działań w kierunku dostosowania zasad prowadzenia hodowli i rozrodu zwierząt w kraju do wymogów unijnych. W efekcie przyjęta została ustawa z 28 października 2020 r. o organizacji hodowli i rozrodzie zwierząt gospodarskich ${ }^{13}$. Objęła ona przedmiot i zakres normowania wskazany w rozporządzeniu, a także pewne rozwiązania istotne dla polskich producentów rolnych, m.in. odnosi się ona do pozostałych gatunków zwierząt gospodarskich, które w poprzednim reżimie prawnym były objęte ustawą, tj. drobiu, zwierząt futerkowych, pszczół i jeleniowatych, a także - co jest novum - alpak i jedwabników morwowych. Reguluje także w całości sprawy organizacji ich hodowli oraz rozrodu.

Jednocześnie w ustawie została podjęta próba zdefiniowania prawodawstwa zootechnicznego, przez które należy rozumieć wszystkie obowiązujące przepisy Unii Europejskiej dotyczące hodowli i rozrodu zwierząt gospodarskich, w tym również rozporządzenie 2016/1012.

Omawiana ustawa reguluje sprawy z zakresu hodowli i oceny wartości użytkowej oraz oceny genetycznej, prowadzenia ksiąg hodowlanych, rejestrów hodowlanych dla świń i rejestrów dla pozostałych zwierząt gospodarskich, a także ochrony zasobów genetycznych oraz nadzoru nad hodowlą i rozrodem wszystkich gatunków zwierząt gospodarskich określonych w rozporządzeniu. Przy opracowaniu jej projektu zastosowano układ dotychczas obowiązującej ustawy z 29 czerwca 2007 r. o organizacji hodowli i rozrodzie zwierząt gospodarskich ${ }^{14}$, która była stosunkowo czytelnym aktem prawnym $^{15}$. Tym samym, aby uniknąć kolizji norm unijnych i krajowych, wyeliminowano z polskiego porządku prawnego przepisy dotyczące samego sposobu prowadzenia ksiąg hodowlanych i rejestrów świń hodowlanych, zasad wpisywania zwierząt do tych ksiąg i rejestrów, zasad prowadzenia oceny wartości użytkowej i genetycznej dla tych gatunków zwierząt, wymogów stawianych zwierzętom hodowlanym czystorasowym wykorzystywanym do

13 Tekst ustawy przekazany do Senatu.

14 Tekst jedn. Dz. U. z 2017 r., poz. 2132.

${ }_{15}$ Uzasadnienie projektu ustawy o organizacji hodowli i rozrodzie zwierząt gospodarskich, Druk nr 512, Warszawa, 17 lipca 2020 r., Sejm RP IX kadencji. 
hodowli i rozrodu, obrotu zwierzętami hodowlanymi czystorasowymi i ich materiałem biologicznym przeznaczonym do wykorzystania $\mathrm{w}$ rozrodzie, a także sposobu przeprowadzania kontroli urzędowych, bowiem zagadnienia te zostały uregulowane w rozporządzeniu 2016/1012, które jest stosowane bezpośrednio od 1 listopada $2018 \mathrm{r}$.

Jeżeli chodzi o rozdział uprawnień i kompetencji określonych prawem unijnym, to zasadniczo zostały one przyznane dwóm podmiotom. Pierwszym z nich jest minister właściwy do spraw rolnictwa, mający kompetencje do uznawania organizacji hodowców lub innych podmiotów, które ubiegają się o prowadzenie ksiąg hodowlanych i rejestrów hodowlanych dla bydła, świń, owiec, kóz i koniowatych, za związki hodowców i przedsiębiorstwa hodowlane. Ponadto w jego gestii leży zatwierdzanie programów hodowlanych, a także nakładanie i cofanie środków określonych w rozporządzeniu 2016/1012, w przypadku gdy kontrolowane podmioty naruszą przepisy rozporządzenia.

Warto podkreślić, że nadal upoważnione związki hodowców lub inne podmioty zachowują prawo do prowadzenia ksiąg hodowlanych lub rejestrów, o ile w terminie 12 miesięcy od dnia wejścia w życie ustawy przedłożą ministrowi właściwemu do spraw rolnictwa dokumenty określone w ustawie. Chodzi m.in. o program hodowlany lub program krzyżowania; oświadczenie o rodzaju oraz posiadanej liczbie zwierząt, które mogą i będą uczestniczyły w realizacji programu hodowlanego; oświadczenie o spełnieniu innych wymagań określonych ustawą; regulamin rozstrzygania sporów między hodowcami uczestniczącymi w programie; kopię statutu lub umowy (art. 10 ust. 4 oraz art. 13 ust. 3 ustawy). Ich niezłożenie będzie skutkować cofnięciem przez ministra właściwego do spraw rolnictwa zezwolenia w tym zakresie. W kwestii istniejących do czasu wejścia w życie ustawy wpisów do ksiąg hodowlanych lub rejestrów dokonanych zgodnie z przepisami uchylanej ustawy z 29 czerwca 2007 r. o organizacji hodowli i rozrodzie zwierząt gospodarskich nie tracą one swojej mocy i będą traktowane tak jak dokonane zgodnie z przepisami nowej ustawy.

Drugim z wymienionych podmiotów jest Krajowe Centrum Hodowli Zwierząt (KCHZ), któremu zostały powierzone kwestie kontroli urzędowej w rozumieniu art. 2 pkt 18 rozporządzenia 2016/1012. Ponadto KCHZ wykonuje wszystkie dotychczasowe zadania w zakresie kontroli sposobu prowadzenia ksiąg hodowlanych, rejestrów hodowlanych dla świń i rejestrów dla pozostałych zwierząt gospodarskich, oceny wartości użytkowej i oceny genetycznej, sposobu wykorzystania środków pochodzących z dotacji budżetowych przyznanych podmiotom realizującym zadania z zakresu postępu biologicznego w produkcji zwierzęcej, prowadzenia laboratorium 
referencyjnego badającego mleko w ramach oceny wartości użytkowej bydła, owiec i kóz. Do kompetencji KCHZ należy też prowadzenie oceny wartości użytkowej lub oceny genetycznej pszczół i stad zwierząt futerkowych. W tym zakresie powtórzono rozwiązania prawne z ustawy z $2007 \mathrm{r}$.

Istotnym rozwiązaniem przyjętym w ustawie jest wprowadzenie przepisów materialnych stanowiących podstawę prawną do udzielania pomocy państwa na prowadzenie ksiąg hodowlanych oraz oceny wartości użytkowej i genetycznej zwierząt gospodarskich. Jednocześnie w art. 53 ustawy określono maksymalny limit wydatków budżetu państwa na lata 2020-2029.

Warto dodać, że możliwość refundowania kosztów realizacji niektórych zadań w zakresie postępu biologicznego w produkcji zwierzęcej dopuszczają przepisy unijne regulujące sprawy dotyczące pomocy państwa w rolnictwie, tj. rozporządzenie Komisji (UE) nr 702/2014 z 25 czerwca 2014 r. uznające niektóre kategorie pomocy w sektorach rolnym i leśnym oraz na obszarach wiejskich za zgodne z rynkiem wewnętrznym w zastosowaniu art. 107 i 108 Traktatu o funkcjonowaniu Unii Europejskiej ${ }^{16}$, a także wytyczne Unii Europejskiej w sprawie pomocy państwa w sektorach rolnym i leśnym oraz na obszarach wiejskich w latach 2014-202017. Zgodnie z tymi przepisami w zakresie hodowli zwierząt gospodarskich hodowcom zwierząt będącym mikroprzedsiębiorcami, małymi lub średnimi przedsiębiorcami w rozumieniu przepisów załącznika I do rozporządzenia nr 702/2014 może być udzielana pośrednio pomoc świadczona w naturze $\mathrm{w}$ formie subsydiowanych usług polegających na prowadzeniu ksiąg hodowlanych (do 100\% kosztów kwalifikujących się do objęcia pomocą) oraz prowadzeniu oceny wartości użytkowej lub hodowlanej zwierząt gospodarskich (do 70\% takich kosztów).

W ustawie uregulowane zostały także nowe kwestie wskazane rozporządzeniem unijnym, tj. dotyczące rozszerzenia geograficznego oraz ras zagrożonych $\mathrm{i}$ ich ochrony. Od strony proceduralnej ustawodawca wskazał jedynie termin, w jakim związki hodowców lub przedsiębiorstwa hodowlane mają obowiązek poinformować ministra właściwego do spraw rolnictwa o zamiarze rozszerzenia obszaru geograficznego, na którym będą realizowały swój program hodowlany, o obszar innego państwa członkowskiego Unii Europejskiej. Natomiast samo postępowanie w sprawie powiadamiania przez właściwy organ państwa członkowskiego, który uznał związek hodowców zamierzający rozszerzyć obszar geograficzny, na którym będzie on realizował swój program hodowlany, o terytorium

\footnotetext{
16 Dz. Urz. UE L 193 z 1.07.2014, s. 1-75.

${ }^{17}$ Dz. Urz. UE C 204 z 1.07.2014, s. 1-97.
} 
innego państwa członkowskiego Unii Europejskiej, zostało określone w art. 12 rozporządzenia 2016/1012.

W treści ustawy zdefiniowane zostały także warunki, jakie muszą zostać spełnione, żeby dana rasa zwierząt gospodarskich lub linia hodowlana pszczół lub ród drobiu zostały uznane za zagrożone i objęte ochroną zasobów genetycznych. Ponadto określone zostały wymagania, jakie powinien spełniać program ochrony zasobów genetycznych (art. 34 ustawy). Do przeprowadzenia badań w zakresie zasadności objęcia ochroną określonych populacji zwierząt gospodarskich, zinwentaryzowania i scharakteryzowania posiadanych zasobów, w tym opracowania krajowego raportu o stanie zasobów genetycznych zwierząt, oraz do monitorowania i prowadzenia krajowych baz danych w tym zakresie wskazany został Instytut Zootechniki - Państwowy Instytut Badawczy w Krakowie (IZ-PIB).

Zgodnie z uzasadnieniem projektu ustawy, mając na względzie dotychczasowe dokonania IZ-PIB w zakresie ochrony in situ i ex situ zwierząt gospodarskich, jego zaplecze badawcze i naukowe, a także zgromadzone w Krajowym Banku Materiału Biologicznego nasienie i zarodki zagrożonych populacji zwierząt gospodarskich, w projekcie ustawy wskazano IZ-PIB jako podmiot odpowiedzialny, przede wszystkim za opracowanie - we współpracy z uznanymi związkami hodowców lub innymi podmiotami prowadzącymi księgi hodowlane dla zagrożonych ras, linii lub rodów - programów ochrony zasobów genetycznych poszczególnych ras, linii lub odmian zwierząt gospodarskich oraz gromadzenie i przechowywanie materiału biologicznego podlegającego kriokonserwacji zgodnie z przyjętym programem ochrony danej rasy, linii lub rodu zwierząt gospodarskich. IZ-PIB jest również odpowiedzialny za informowanie właściwych miejscowo powiatowych lekarzy weterynarii o liczbie i miejscu utrzymywania zwierząt poszczególnych gatunków objętych ochroną zasobów genetycznych oraz za współpracę i koordynację współpracy z organizacjami międzynarodowymi lub ponadnarodowymi działającymi w dziedzinie ochrony zasobów genetycznych zwierząt gospodarskich (art. 34 ust. 3 pkt 4 i 5 ustawy).

4. W efekcie wprowadzenia rozporządzenia 2016/1012 nastąpiło przekształcenie i pewne uproszczenie europejskiego prawodawstwa zootechnicznego (prawa hodowlanego). Tym samym zostały stworzone jednolite ramy prawne dla wolnego handlu zwierzętami hodowlanymi i ich materiałem genetycznym, odzwierciedlające postęp techniczny w produkcji zwierzęcej. Możliwość podejmowania działań transgranicznych przez związki hodowców stała się więc gwarancją uczciwej konkurencji. 
Z kolei przyjęcie w kraju nowej ustawy o organizacji hodowli i rozrodzie zwierząt gospodarskich pozwala na pełne i prawidłowe wykonanie rozporządzenia unijnego, a także zapewnienie trwałości prowadzenia hodowli zwierząt gospodarskich dzięki ciągłości prowadzenia ksiąg hodowlanych i rejestrów oraz prowadzenia oceny wartości użytkowej i genetycznej zwierząt.

Podejmując próbę oceny nowego unijnego prawa hodowlanego, a przez jego pryzmat rozwiązań prawnych przyjętych w kraju, należy stwierdzić, że pozwalają one na płynne i efektywne prowadzenie działalności hodowcom. Wyrazem tego jest zagwarantowanie im jednakowych praw i obowiązków na terenie całej Unii. Z kolei wejście w życie krajowej ustawy o organizacji hodowli i rozrodzie zwierząt gospodarskich nie wpłynie na sposób prowadzenia przez nich hodowli, a tym samym nie zostaną oni obciążeni żadnymi nowymi obowiązkami wynikającymi z nowych przepisów. Jednocześnie ustawodawca zapewnia związkom hodowców i przedsiębiorstwom hodowlanym możliwość kontynuowania działalności pod warunkiem dostosowania się do przepisów rozporządzenia 2016/1012. Oznacza to opracowanie nowych programów hodowlanych dla prowadzonych ksiąg hodowlanych zgodnie z wymogami określonymi w rozporządzeniu 2016/1012.

Przyjęte rozwiązania prawne służą producentom, zwiększając zaufanie do wartości genetycznej zwierząt hodowlanych i ich materiału biologicznego oferowanego na rynku wewnętrznym. Pozytywnie oddziałują także na konsumentów produktu finalnego pochodzenia zwierzęcego. Dzięki postępowi w hodowli mogą oni spodziewać się zwiększenia opłacalności produkcji, a tym samym spadku cen żywności ${ }^{18}$.

\title{
SELECTED LEGAL ISSUES OF LIVESTOCK FARMING IN THE LIGHT OF NEW LEGAL REGULATIONS
}

\author{
Summary
}

The purpose of the considerations was to answer the question whether the legal standards governing livestock farming adopted at the EU level serve the purpose of proper organisation of animal husbandry and whether the Polish legislator has ensured appropriate solutions enabling proper implementation of European Union law. The conclusions of the considerations are that European Zootechnical Legislation has been simplified, allowing for a smooth and effective conduct of livestock farming. The new Act on the organisation of breeding and reproduction of farm animals enables full and correct implementation of the EU regulation in Poland. At the same time, the requirement arising from the Act to conduct assessments of the utility and genetic value of animals and to maintain herd books and records guarantee the durability of livestock farming.

${ }^{18}$ Szerzej: E. Martyniuk, A. Chełmińska, Nowa legislacja..., s. 53. 


\title{
SULLE QUESTIONI GIURIDICHE \\ RIGUARDANTI L'ALLEVAMENTO DEL BESTIAME ALLA LUCE DI NUOVE REGOLAZIONI GIURIDICHE
}

\begin{abstract}
Riassunto
L'articolo si propone di stabilire se le norme giuridiche, adottate a livello dell'UE in materia di allevamento del bestiame, aiutino a gestire l'allevamento in modo giusto, nonché se il legislatore nazionale abbia previsto soluzioni adeguate al fine di applicare il diritto dell'UE in modo corretto. Nella parte conclusiva, le autrici affermano che la legislazione zootecnica è stata semplificata, il che permette di svolgere l'attività di allevamento senza difficoltà e in modo efficace. L'adozione di una nuova legge, volta a disciplinare l'organizzazione dell'allevamento e la riproduzione del bestiame, consentirebbe l'attuazione della normativa dell'UE in modo pieno e corretto. Allo stesso tempo, assicurando la continuità della tenuta dei libri genealogici e dei registri, nonché effettuando la valutazione delle prestazioni e del valore genetico del bestiame, la durabilità dell'allevamento sarebbe garantita.
\end{abstract}

